\title{
Crystallization kinetics of calcium oxalate monohydrate in the presence of amino acids
}

\author{
Y.V.Taranets, O.N.Bezkrovnaya, I.M.Pritula \\ Institute for Single Crystals, STC "Institute for Single Crystals", National \\ Academy of Sciences of Ukraine, 60 Nauky Ave., 61001 Kharkiv, Ukraine
}

\section{Received January 18, 2018}

\begin{abstract}
Studied is the effect of L-aspartic acid (L-Asp), L-arginine (L-Arg) and L-threonine (L-Thr) on the crystallization kinetics of calcium oxalate monohydrate (COM). L-Asp and L-Arg amino acids exert an inhibitory effect on COM crystallization. Addition of 1-20 mM of L-Asp and L-Arg to the calcium oxalate model system increases the induction time in comparison with that of pure COM by 3-10 and 1.3-6 times, respectively. The degree of inhibition of COM crystallization is $86.0 \%$ (for $20 \mathrm{mM}$ of L-Arg) and $90.2 \%$ (for $20 \mathrm{mM}$ of L-Asp) due to high adsorption capacity of these molecules on COM crystal faces. L-Thr amino acid is a promoter of COM crystallization; the induction time is reduced by 2 times as against that of pure microcrystals.

Keywords: calcium oxalate monohydrate, spectrophotometry, nucleation, L-aspartic acid, L-arginine, L-threonine.
\end{abstract}

Исследовано влияние L-аспарагиновой кислоты (L-Asp), L-аргинина (L-Arg) и L-треонина (L-Thr) на кинетику кристаллизации оксалата кальция моногидрата (COM). Установлено, что аминокислоты L-Asp и L-Arg оказывают ингибирующее действие на процессы кристаллизации COM. Добавление L-Asp и L-Arg в модельную систему оксалата кальция в концентрации 1-20 ммоль/л приводит к увеличению времени индукции, соответственно, в 3-10 и 1.3-6 раз по сравнению с кристаллизацией СОМ без добавок. Степень ингибирования кристаллизации при 20 ммоль/л L-Arg и 20 ммоль/л L-Asp составляет 86.0 \% и $90.2 \%$, соответственно, что обусловлено высокой адсорбционной способностью L-Arg и L-Asp на грани COM. Обнаружено, что L-Thr является промоутером кристаллизации COM; время индукции уменьшается в 2 раза по сравнению с кристаллизацией чистых СОМ.

Кінетика кристалізації оксалату кальцію моногідрату у присутності амінокислот. Ю.В.Таранець, О.М.Безкровна, І.М.Притула.

Досліджено вплив L-аспарагінової кислоти (L-Asp), L-аргініну (L-Arg) i L-треоніну (L-Thr) на кінетику кристалізації оксалату кальцію моногідрату (COM). Встановлено, що амінокислоти L-Asp i L-Arg чинять інгібуючу дію на процеси кристалізації COM. Додавання L-Asp i L-Arg у модельну систему оксалату кальцію у концентрації 120 ммоль/л призводить до збільшення часу індукції, відповідно, в 3-10 і 1.3-6 рази у порівнянні з кристалізацією СОМ без добавок. Ступінь інгібування кристалізації при 20 ммоль/л L-Arg i 20 ммоль/л L-Asp становить $86.0 \%$ i $90.2 \%$, відповідно, що обумовлено високою адсорбційною здатністю L-Arg i L-Asp на поверхні кристалів COM. Виявлено, що амінокислота L-Thr е промоутером кристалізації COM; час індукції зменшується у 2 рази у порівнянні з кристалізацією чистих COM.

\section{Introduction}

Biological liquids are complex multicomponent systems that play a huge role in providing vital functions of human organ- ism. Functioning of the latter and processes which occur in it are very closely interrelated: disturbance of the function of any process gives rise to many negative conse- 
quences. Pathogenic crystallization is one of such disturbances is, that result a formation of crystals from bio fluid with subsequent appearance of stones, in particular, of kidney stones. Therefore, identification of the mechanisms of the formation of pathogenic aggregates and the kinetics of their growth is a topical problem. The influence of molecules of different nature (amino acids, proteins, inorganic and surface-active substances) on the formation of COM microcrystals and their growth kinetics was investigated in a number of papers [1-4].

In this paper, we studied the crystallization kinetics of calcium oxalate monohydrate (COM), one of the main components of kidney stones $[5,6]$, in the presence of L-aspartic acid (L-Asp), L-arginine (L-Arg) and L-threonine (L-Thr) amino acids. The choice of amino acids is due to their content in the physiological fluid and kidney stones [7]. These amino acids dissociate in water medium and have different charge states in the calcium oxalate model system [8].

It is known, that L-Asp $\left(\mathrm{COOH}-\mathrm{CH}_{2}-\right.$ $\left.\mathrm{CH}\left(\mathrm{NH}_{2}\right)-\mathrm{COOH}\right)$ amino acid, with two carboxyl groups and one amino group in its structure, belongs to acidic amino acids. The isoelectric point for L-Asp is 2.77, and the dissociation constants (pK) for L-Asp are 1.95, 3.71 and 9.66 [9]. L-Arg $\left(\mathrm{C}(\mathrm{NH})\left(\mathrm{NH}_{2}\right)-\mathrm{NH}-\left(\mathrm{CH}_{2}\right)_{3}-\mathrm{CH}\left(\mathrm{NH}_{2}\right)-\mathrm{COOH}\right)$ is a basic amino acid due to the presence of one carboxyl group and two basic centers (amino- and guanidine groups). The isoelectric point for L-Arg is 10.76, and its pK values are 2.03, 9.00 and 12.10 [9]. L-Arg molecules are in the cationic form in the solution with $\mathrm{pH} 5.8$ that distinguishes them radically from L-Asp molecules, which are mainly in anionic form under these conditions.

L-Thr $\left(\mathrm{CH}_{3}-\mathrm{CH}(\mathrm{OH})-\mathrm{CH}\left(\mathrm{NH}_{2}\right)-\mathrm{COOH}\right)$ contains one carboxyl group and one amino group and belongs to neutral amino acids. Accordingly, L-Thr has two pK values (2.20 and 8.97), and its isoelectric point is 5.6 [8]. Therefore, it is most probable that L-Thr amino acid exists in the zwitterionic form in the solution with $\mathrm{pH} 5.8$.

Investigation of the effect of the charge state of L-Asp, L-Arg and L-Thr amino acids on COM crystallization will allow to estimate the induction time and possible inhibition of crystal growth.

Various methods have been used to study the growth of COM crystals, but many of them are either laborious or require expensive equipment $[1,10]$. In our work, the effect of L-Asp, L-Arg and L-Thr amino acids on the growth kinetics of COM crystals was investigated using spectrophotometric method by comparing the growth rate of COM crystals in the presence and in the absence of the additives. This method is easy to carry out, and at the same time makes it possible to determine the effect of modifier molecules (in our study, amino acids) on COM crystallization. Therefore, the aim of the work was to study the effect of amino acids with different charge states (L-Asp, L-Arg and L-Thr) within a wide range of their concentrations on COM crystallization kinetics.

\section{Experimental}

The crystallization kinetics of calcium oxalate monohydrate was carried out in a model system, closest to the physiological conditions in human body $[10,11]$. The model solution was formed based on the following composition: calcium chloride $\left(\mathrm{CaCl}_{2}\right)$, potassium oxalate $\left(\mathrm{K}_{2} \mathrm{C}_{2} \mathrm{O}_{4} \cdot \mathrm{H}_{2} \mathrm{O}\right)$, potassium chloride $(\mathrm{KCl})$, acetate buffer solution, amino acids (L-Asp, L-Arg and L-Thr) and distilled water. The molar concentrations ratio of the stone-forming components $\left[\mathrm{Ca}^{2+}\right] /\left[\mathrm{C}_{2} \mathrm{O}_{4}{ }^{2-}\right]$ of the reaction was $20: 1$. The acidity of the solutions $(\mathrm{pH}=5.8)$ and the ionic strength $(0.15 \mathrm{M})$ were constant in all the cases.

Supersaturation of the solutions ( $s$ ) was calculated by means of the formula given in $[5,13]$. The concentration of the amino acids (L-Asp, L-Arg and L-Thr) in the model solutions varied in the range of $1-20 \mathrm{mM}$, which is comparable with their concentrations in physiological fluids.

The formation of calcium oxalate monohydrate phase was confirmed by X-ray diffraction (a diffractometer "DRON-2-M") and IR spectroscopy (a spectrophotometer "Spectrum One PerkinElmer") [12, 14].

COM crystallization was carried out at $s=4.6$ in the presence of amino acids to determine their possible adsorption to COM crystal faces. The volumes of calcium chloride and potassium oxalate solutions for the synthesis of COM microcrystals with and without amino acid additives, were the same. A day later the resulting suspensions of COM microcrystals were washed 3 times in distilled water and centrifuged. Then the suspension samples were diluted by distilled water to obtain a volume of $5 \mathrm{ml}$ and measured using an Optizen 3220UV spectrophotometer in the wavelength range of 190-700 $\mathrm{nm}$.

The kinetics of COM crystallization without additives and in the presence of L-Asp, L-Arg and L-Thr amino acids was estimated 

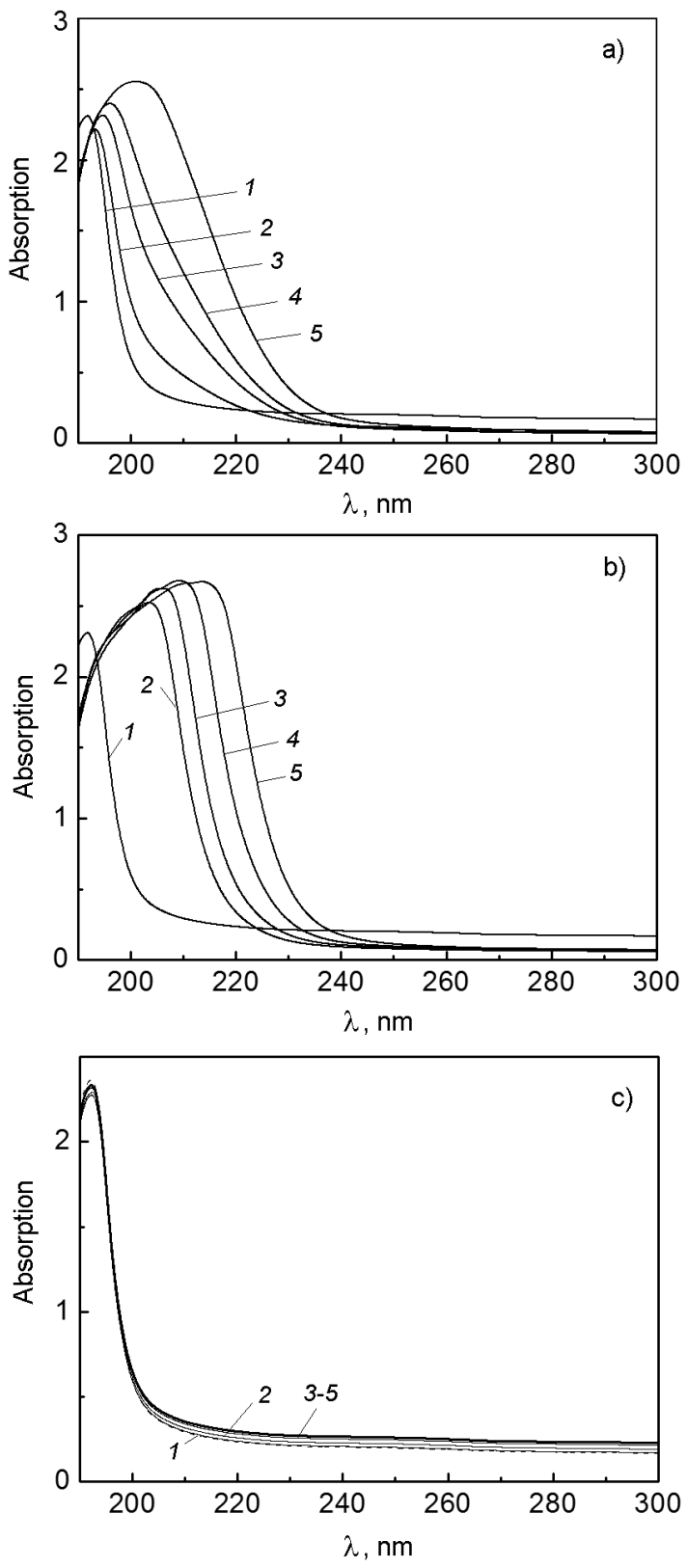

Fig. 1. Absorption spectra of COM microcrystals in water. COM microcrystals were synthesized without additives (1) and with the addition of L-Asp (a), L-Arg (b), L-Thr (c) amino acids and then washed 3 times by distilled water. The additives were of the concentrations: $2 \mathrm{mM}(2), 4 \mathrm{mM}(3), 8 \mathrm{mM}(4), 20 \mathrm{mM}$ (5) $(s=4.6 ; \mathrm{pH}=5.8,0.15 \mathrm{M}$ ionic strength).

using the spectrophotometric method by measuring turbidity of solutions as described in $[7,15,16]$. The supersaturation of all the solutions was the same $(s=6.0)$, and optimal for determination of the induction time $(\tau)$. COM crystallization without additives proceeded very rapidly at $s>8$, which introduced an inaccuracy in $\tau$ determination. At

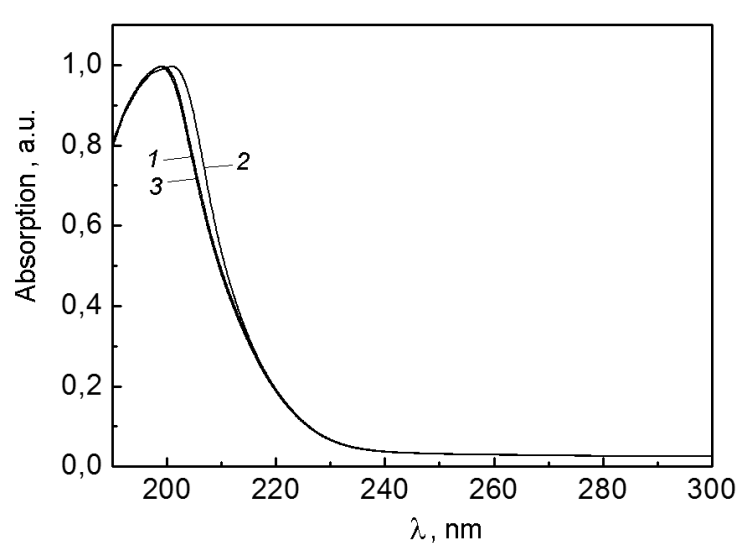

Fig. 2. Normalized absorption spectra of L-Asp (1), L-Arg (2) and L-Thr (3) amino acids of $1 \mathrm{mM}$ concentration in water.

low supersaturations $(s<5)$ and high concentrations of the inhibitors (14-20 mM) the crystallization proceeded very slowly.

The induction time and the turbidity slope, as a function of time was determined for pure suspensions and for those containing the additives. The optical density of the model solutions was measured by a spectrophotometer at $620 \mathrm{~nm}$. The optical density of the solutions at $620 \mathrm{~nm}$ was directly proportional to the mass of COM crystals formed per unit volume [7, 17, 18]. The percentage of inhibition of COM crystal growth $(I, \%)$ by amino acid molecules was calculated according to [7]:

$$
I=\left[1-T_{s i} / T_{s c}\right] \cdot 100,
$$

where $T_{s c}$ and $T_{s i}$ are the turbidity slopes for the suspensions without additives and for those containing amino acid, respectively.

\section{Results and discussion}

To reveal the influence of the amino acids on COM crystallization and their possible adsorption on the surface of the growing crystal faces there were measured the absorption spectra of the washed COM microcrystals synthesized without additives and in the presence of L-Asp, L-Arg, L-Thr amino acids (Fig. 1 ), as well as the spectra of water solutions of amino acids (Fig. 2). The absorption maximum for pure COM microcrystals is located at $192 \mathrm{~nm}$. The shift of the absorption maximum towards larger wavelengths with the rise of the concentration of L-Asp and L-Arg amino acids was observed during COM synthesis (Fig. 1a, b). This may be due to the adsorption of L-Asp and L-Arg amino acids on COM crystal surface. As reported in [13], the maximum of L-Arg absorption in the aqueous 


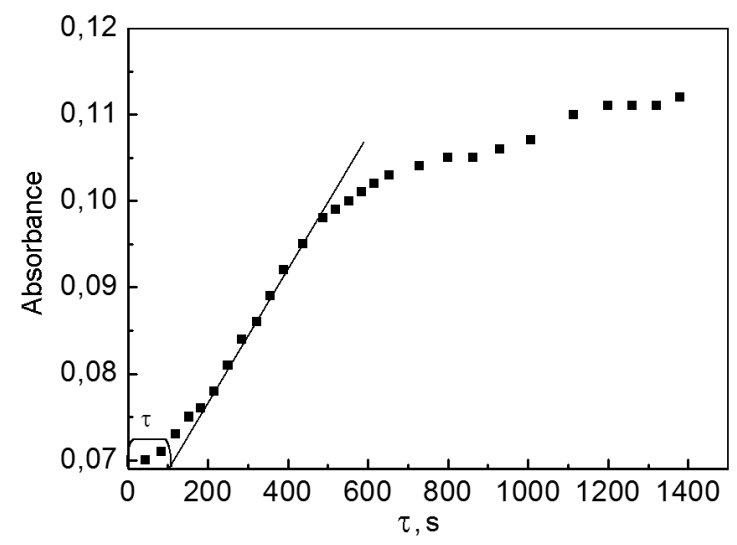

Fig. 3. Typical curve of pure COM crystallization $(s=6.0 ; \mathrm{pH}=5.8 ; 0.15 \mathrm{M}$ ionic strength).

Table. Effect of amino acids concentration on COM crystallization

\begin{tabular}{||c|c|c|c||}
\hline Crystals & $c, \mathrm{mM}$ & $\tau, \mathrm{s}$ & $I, \%$ \\
\hline Pure COM & - & 100 & - \\
\hline COM+L-Asp & 1 & 300 & 32.0 \\
& 2 & 300 & 42.8 \\
& 4 & 410 & 64.6 \\
& 8 & 600 & 72.2 \\
& 14 & 970 & 89.5 \\
& 20 & 990 & 90.2 \\
\hline COM+L-Arg & $1-2$ & 100 & 0 \\
& 4 & 130 & 0.5 \\
& 8 & 280 & 10.2 \\
& 14 & 570 & 66.7 \\
& 20 & 600 & 86.0 \\
\hline COM+L-Thr & 1 & 100 & 0 \\
& $2-20$ & 50 & 0 \\
\hline
\end{tabular}

$c-$ is the concentrations inhibitor, $\mathrm{mM}$; $\tau$, the induction time, $\mathrm{s} ; I$, the degree of inhibition of COM crystallization, $\%$.

solution is located in the region of $220 \mathrm{~nm}$. The spectra of L-Asp, L-Arg and L-Thr absorption in water showed the absorption maxima at 200-202 $\mathrm{nm}$ (Fig. 2).

As seen from Fig. 1c, the absorption spectra of COM crystals with L-Thr in concentrations of 2-20 $\mathrm{mM}$ are practically similar to those of COM crystals not containing the additives. The absence of changes in the absorption maxima and the spectral widths of the doped samples in comparison with pure COM testifies that L-Thr molecules are not adsorbed on COM crystal surfaces.
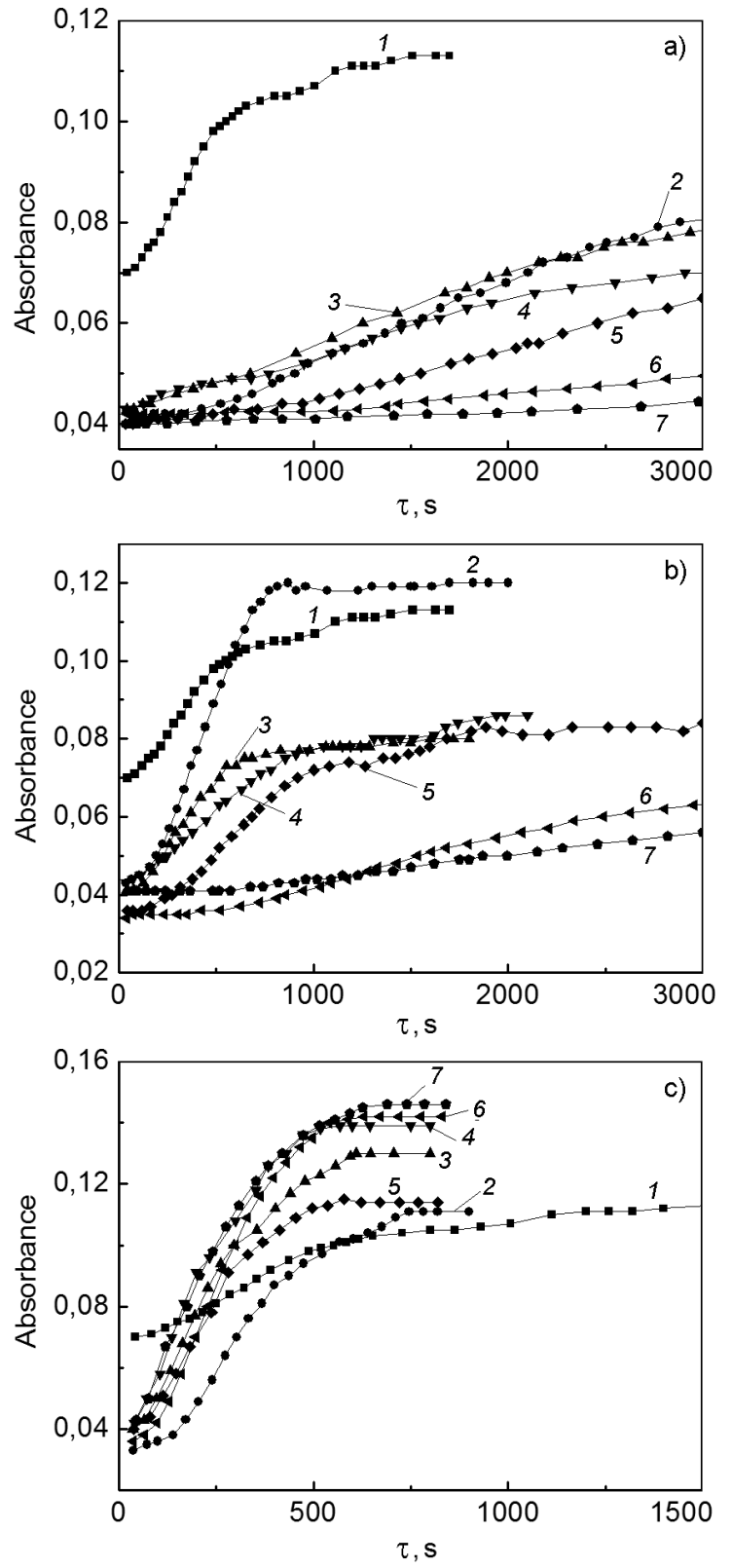

Fig. 4. Kinetic curves of COM crystallization with the addition of L-Asp (a), L-Arg (b), L-Thr (c) of the concentrations: $0 \mathrm{mM}$ (1), $1 \mathrm{mM}$ (2), $2 \mathrm{mM} \mathrm{(3),} 4 \mathrm{mM}$ (4), $8 \mathrm{mM}$ (5), $14 \mathrm{mM}(6), 20 \mathrm{mM}(7)$.

The kinetic curves of crystallization of COM suspensions with L-Asp, L-Arg, and L-Thr (Fig. 3, Fig. 4) and of the ones without additives allow to reveal the effect of the amino acids on the nucleation and growth of COM crystals. The induction times for the investigated systems determined from the kinetics curves (Fig. 3) varied in the range of $100-1000 \mathrm{~s}$. For pure COM solutions $(s=6.0) \tau=100 \mathrm{~s}$ and rises with the addition of L-Asp in 1-20 mM con- 
centration (Table): $\tau=300 \mathrm{~s}$ at $1-2 \mathrm{mM}$ of L-Asp, $990 \mathrm{~s}$ at $20 \mathrm{mM}$ of L-Asp, respectively. This testifies to an inhibitory effect of L-Asp on COM crystallization. The kinetics curves (Fig. 3a) show that such an effect enhances with the increase of L-Asp concentration. Accordingly, the degree of inhibition of COM crystallization rises from $32.0 \%$ (for $1 \mathrm{mM}$ of L-Asp) to $90.2 \%$ (for $20 \mathrm{mM}$ of L-Asp).

The inhibitory effect is less pronounced if L-Arg is used instead of L-Asp. The induction time increases with the addition of more than $2 \mathrm{mM}$ L-Arg to the model system, and $\tau=600 \mathrm{~s}$ at $20 \mathrm{mM}$ L-Arg (Table). The degree of inhibition of COM crystallization is $0.5 \%$ and $86.0 \%$ with the use of $4 \mathrm{mM}$ and $20 \mathrm{mM}$ of L-Arg, respectively. In contrast to L-Asp and L-Arg, L-Thr molecules induce a promoting effect on COM growth kinetics. The induction time of COM crystallization with a very low concentration of L-Thr $(1 \mathrm{mM})$ corresponds to that for pure COM $(100 \mathrm{~s})$, but the induction time decreases to $50 \mathrm{~s}$ at $2-20 \mathrm{mM}$ of L-Thr. Being active centers of crystallization, L-Thr molecules probably increase the number of nuclei in the system, raises the rate of COM crystallization.

The significant inhibitory effect of L-Asp molecules on COM crystallization is due to the anionic form of L-Asp molecules in this system. Adsorption of L-Asp may be caused by the electrostatic interaction of its two negatively charged carboxyl groups and the positively charged faces of COM crystals.

The inhibitory effect of L-Arg molecules is explained by the Dyuklo-Traube rule [19]. Colloidal surfactants possess a high adsorption capacity mainly depending on hydrocarbon radical length, and the surface activity of molecule rises with this length. L-Arg molecule structure contains by two hydrocarbon groups more than L-Asp molecule, and has a branched structure due to the presence of a guanidine group. This feature provides adsorption of L-Arg molecules on the positively charged faces of COM microcrystals, in contrast to L-Asp molecules, which adsorption on the crystal faces is caused both by the formation of hydrogen bonds and electrostatic interaction with the microcrystal surface.

\section{Conclusions}

Studied was the effect of L-Asp, L-Arg and L-Thr amino acids and their concentrations in the model system on the crystallization kinetics of calcium oxalate monohydrate.
L-Asp and L-Arg molecules were found to exert a significant inhibitory effect on COM crystals growth. The addition of $20 \mathrm{mM}$ of L-Asp to the model system results in $90.2 \%$ inhibition of COM crystal growth and in the rise of the induction time by almost 10 times compared to that of pure COM. The introduction of $20 \mathrm{mM}$ of L-Arg increases the induction time by 6 times, and the degree of COM inhibition is $86.0 \%$. The significant inhibitory effect of L-Asp and L-Arg is due to adsorption of the amino acid molecules on the growing faces of COM crystals. L-Thr amino acid is a promoter of COM crystallization. The induction time reduces by two times with the addition of $2-20 \mathrm{mM}$ of L-Thr compared to the one at pure COM crystallization.

\section{References}

1. L.Tunik, L.Addadi, N.Garti et al., J.Cryst. Growth, 167, 748 (1996).

2. P.Bhadja, J.Lunagariya, J.-M.Ouyang, $J$. Funct. Foods, 27, 685 (2016).

3. Sh.Guo, M.D.Ward, J.A.Wesson, Langmuir, 18, 4284 (2002).

4. F.Grases, J.G.March, F.Bibiloni et al., $J$. Cryst. Growth, 87, 299 (1988).

5. T.Sugimoto, Y.Funae, H.Rubben et al., Eur. Urol., 11, 334 (1985).

6. J.He, R.Lin, H.Long et al., J.Colloid Interface Sci., 454, 144 (2015).

7. C.Hennequin, V.Lalanne, M.Daudon et al., Urol. Res., 21, 101 (1993).

8. D.R.Lide, CRC Handbook of Chemistry and Physics, 90th Edition, CRC Press, Boca Raton, FL (2010).

9. D.E.Fleming, W.Bronswijk, R.L.Ryall, Clin. Sci., 101, 159 (2001).

10. P.Kavanagh, L.Jones, P.N.Rao, Urol.Res., 27, 231 (1999).

11. Y.Ogawa, T.Miyazato, T.Hatano, J.Surg., 24, 1154 (2000)].

12. Y.V.Taranets, O.N.Bezkrovnaya, I.M.Pritula et al., Nanosist. Nanomater. Nanotehnol., 14, 445 (2016) (in Russian).

13. S.Kumar, S.B.Rai, Indian J.Pure Appl. Phys., 48, 251 (2010).

14. Y.V.Taranets, O.N.Bezkrovnaya, I.M.Pritula et al., J.Nanomat. and Mol.Nanotechnol., 6 , 1000229 (2017).

15. P.A.Antinozzi, C.M.Brown, D.L.Purich, J. Cryst. Growth, 125, 215 (1992).

16. S.Saha, R.J.Verma, J. Herbal Medic., 5, 41 (2015).

17. G.Dezelic, N.Dezelic, B.A.Tezac, J.Coll.Sci., 18, 888 (1963).

18. D.H.Melik, H.S.Fogler, $J$ Coll. Interf.Sci., 92, 161 (1983).

19. P.M.Kruglyakov, Hydrophile-Lipophile Balance of Surfactants and Solid Particles: Physicochemical Aspects and Applications, Elsevier, New York (2000). 